\title{
Drifting snow climate of the Greenland ice sheet: a study with a regional climate model
}

\author{
J. T. M. Lenaerts ${ }^{1}$, M. R. van den Broeke ${ }^{1}$, J. H. van Angelen ${ }^{1}$, E. van Meijgaard ${ }^{2}$, and S. J. Déry ${ }^{3}$ \\ ${ }^{1}$ Institute for Marine and Atmospheric research Utrecht, Utrecht University, Utrecht, The Netherlands \\ ${ }^{2}$ Royal Netherlands Meteorological Institute, De Bilt, The Netherlands \\ ${ }^{3}$ University of Northern British Columbia, Prince George, Canada
}

Correspondence to: J. T. M. Lenaerts (j.lenaerts@uu.nl)

Received: 20 March 2012 - Published in The Cryosphere Discuss.: 3 May 2012

Revised: 18 July 2012 - Accepted: 3 August 2012 - Published: 15 August 2012

\begin{abstract}
This paper presents the drifting snow climate of the Greenland ice sheet, using output from a high-resolution $(\sim 11 \mathrm{~km})$ regional climate model. Because reliable direct observations of drifting snow do not exist, we evaluate the modeled near-surface climate instead, using automatic weather station (AWS) observations from the K-transect and find that RACMO2 realistically simulates near-surface wind speed and relative humidity, two variables that are important for drifting snow. Integrated over the ice sheet, drifting snow sublimation $\left(\mathrm{SU}_{\mathrm{ds}}\right)$ equals $24 \pm 3 \mathrm{Gt} \mathrm{yr}^{-1}$, and is significantly larger than surface sublimation $\left(\mathrm{SU}_{\mathrm{s}}, 16 \pm 2 \mathrm{Gt} \mathrm{yr}^{-1}\right)$. $\mathrm{SU}_{\mathrm{ds}}$ strongly varies between seasons, and is only important in winter, when surface sublimation and runoff are small. A rapid transition exists between the winter season, when snowfall and $\mathrm{SU}_{\mathrm{ds}}$ are important, and the summer season, when snowmelt is significant, which increases surface snow density and thereby limits drifting snow processes. Drifting snow erosion $\left(E_{\mathrm{ds}}\right)$ is only important on a regional scale. In recent decades, following decreasing wind speed and rising near-surface temperatures, $\mathrm{SU}_{\mathrm{ds}}$ exhibits a negative trend $\left(0.1 \pm 0.1 \mathrm{Gt} \mathrm{yr}^{-1}\right)$, which is compensated by an increase in $\mathrm{SU}_{\mathrm{s}}$ of similar magnitude.
\end{abstract}

\section{Introduction}

The Greenland ice sheet (GrIS) is the largest body of ice in the Northern Hemisphere, containing approximately $7 \mathrm{~m}$ sea level equivalent (IPCC AR4). In the last two decades, numerous Greenland outlet glaciers have accelerated and surface mass balance (SMB) has declined (Rignot et al., 2011), both contributing about equally to recent Greenland mass loss (Van den Broeke et al., 2009). The volume loss of outlet glaciers may be primarily related to oceanic warming (Holland et al., 2008), but the interaction between ocean and outlet glaciers is complex (Nick et al., 2009; Straneo et al., 2011). At the same time, Greenland has experienced significant atmospheric warming in the recent two decades (Box and Cohen, 2006), increasing surface meltwater production and subsequent runoff (Ettema et al., 2009), extending the length of the melt season (Fettweis et al., 2011) and triggering the melt-albedo feedback (Tedesco et al., 2010).

To assess the surface mass balance (SMB) of the GrIS, regional climate models are useful tools. In the SMB of the GrIS, precipitation $(P)$ is the main source of mass, whereas mass is lost by surface $\left(\mathrm{SU}_{\mathrm{S}}\right)$ and drifting snow sublimation $\left(\mathrm{SU}_{\mathrm{ds}}\right)$, drifting snow erosion $\left(\mathrm{ER}_{\mathrm{ds}}\right)$ and meltwater runoff (RU). $E R_{\mathrm{ds}}$ is defined as the horizontal divergence of the snow transport $\left(\mathrm{TR}_{\mathrm{ds}}\right)$. Until now, drifting snow processes have usually been neglected in GrIS SMB studies (Fettweis, 2007; Hanna et al., 2005; Ettema et al., 2009). On the Antarctic ice sheet, drifting snow sublimation $\left(\mathrm{SU}_{\mathrm{ds}}\right)$ is an important ablation term in dry and windy areas and $\mathrm{ER}_{\mathrm{ds}}$ redistributes snow on a local to regional scale (Lenaerts and van den Broeke, 2012). Several studies estimated $\mathrm{SU}_{\mathrm{ds}}$ for Greenland (Déry and Yau, 2002; Box et al., 2006) and ER $_{\mathrm{ds}}$ (Déry and Yau, 2002), using parameterizations based on wind speed (Déry and Yau, 1999), neglecting feedbacks to the overlying atmosphere and the snow surface, which are known to be important (Bintanja, 2001; Lenaerts et al., 2010, 2012a; Gallée et al., 2001). 
Here we present the drifting snow climate (1960-2011) of the Greenland ice sheet using a regional atmospheric climate model (RACMO2) at relatively high horizontal resolution $(11 \mathrm{~km})$. RACMO2 includes an interactive drifting snow routine (Lenaerts et al., 2012a). We discuss the spatial and temporal variability of $\mathrm{SU}_{\mathrm{ds}}$ and $\mathrm{ER}_{\mathrm{ds}}$ and their impact on the SMB of the GrIS.

\section{Methods}

\subsection{Numerical setup}

The Regional Atmospheric Climate MOdel version 2 (RACMO2 hereafter; Van Meijgaard et al., 2008) combines the dynamical parameterizations from the HIgh Resolution Limited Area Model (HIRLAM) (Undén et al., 2002) with the physical schemes from the European Centre for Medium-Range Weather Forecasts model (ECMWF cycle 23r4, White, 2001). In recent years, RACMO2 has been used to estimate the SMB of Antarctica (Van de Berg et al., 2005; Lenaerts et al., 2012b) and Greenland (Ettema et al., 2009). Modeled precipitation and surface mass balance have been extensively evaluated using available in-situ observations (Ettema et al., 2009). Moreover, Ettema et al. (2010b) showed that RACMO2 provides a realistic simulation of the near-surface climate of the GrIS, although several deficiencies were detected, especially in the snow albedo scheme. To resolve this, we included a snow albedo parameterization based on the growth of snow during dry and wet metamorphosis, so that snow albedo can be physically coupled to snow grain size (Flanner and Zender, 2006). This significantly improved net shortwave radiation in RACMO2 over the Antarctic ice sheet (Kuipers Munneke et al., 2011) and the length of the melt season in Greenland (Van Angelen et al., 2012). In addition, a remote sensing-derived background albedo (from the Moderate Resolution Imaging Spectroradiometer, MODIS) is prescribed for ice (Van Angelen et al., 2012) to capture the spatial variability of albedo in the ablation area when the winter snow has melted (Van den Broeke et al., 2008). Finally, the drifting snow scheme derived from Déry and Yau (1999) has been included in RACMO2. It calculates drifting snow transport and sublimation, and accounts for interactions between the drifting snow layer with both the overlying atmosphere and the underlying snow surface (Lenaerts et al., 2010). Furthermore, we use an empirically derived parameterization for surface snow density. This was derived by Lenaerts et al. (2012a) for Antarctica, such that modeled drifting snow frequency and horizontal transport agree well with available in-situ and remote sensing observations (Lenaerts et al., 2012a).

For the GrIS, RACMO2 has 40 levels in the vertical and the model grid has a horizontal spacing of $\sim 11 \mathrm{~km}$. It is forced at its lateral boundaries by ECMWF reanalyses, ERA-40 (1960-1988) and ERA-Interim (1989-2011), at

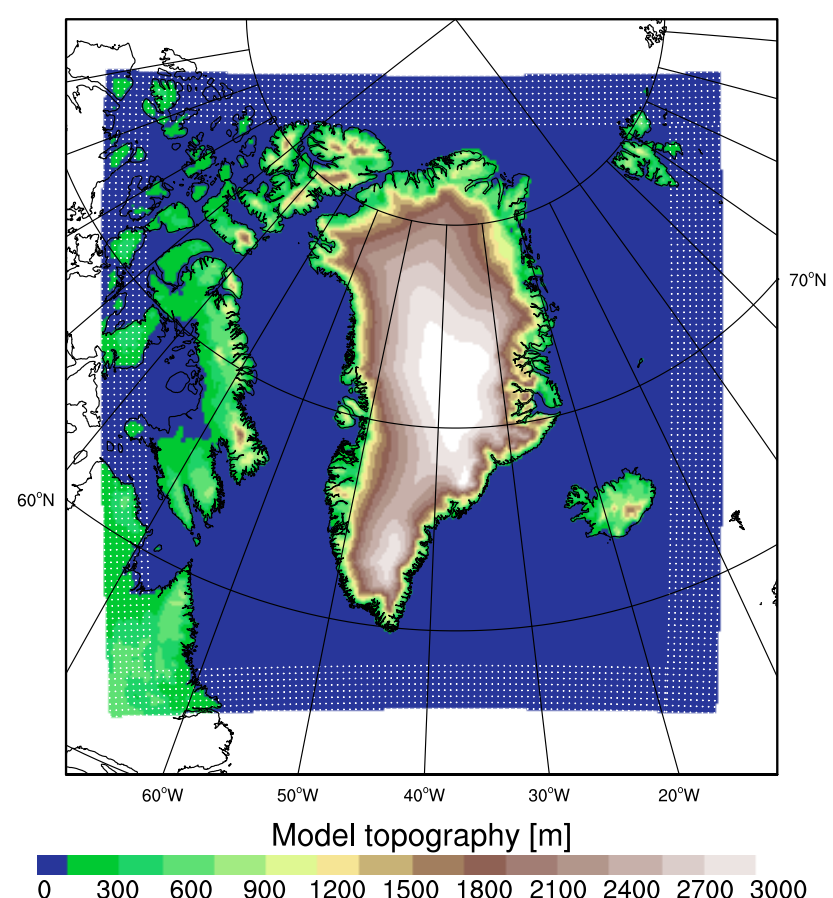

Fig. 1. Overview of model domain. Model topography is shown in colors; blue represents ocean. The white dotted boundary represents the model relaxation zone ( 24 grid points).

a 6-hourly resolution. The atmospheric fields from the reanalyses are relaxed towards true model resolution $(11 \mathrm{~km})$ in the relaxation zone (see Fig. 1). Sea surface temperature (SST) and sea ice extent are prescribed as a surface boundary condition by the reanalyses. Within the interior model domain, RACMO2 evolves freely.

\subsection{Model evaluation}

To date, no reliable direct observations of drifting snow processes on Greenland exist. In-situ instruments are prone to extreme weather conditions, and measurement errors increase with wind speed (Cierco et al., 2007). Remote-sensed observations of drifting snow, shown to be promising on Antarctica (Palm et al., 2011), are limited on Greenland due to enhanced cloudiness and generally shallower drifting snow layers (S. P. Palm, personal communication, 2011). Instead, we focus the evaluation of RACMO2 on the nearsurface climate. Drifting snow predominantly occurs in the surface layer, in the first few meters above the surface. Nearsurface parameters determine the occurrence and strength of drifting snow processes. Therefore, a key component of the model evaluation is to determine the model's ability to simulate a realistic near-surface climate on the GrIS. Primarily near-surface wind speed drives drifting snow processes. Other important atmospheric parameters that control the amount of drifting snow sublimation are near-surface temperature $\left(T_{2} \mathrm{~m}\right)$ and near-surface specific humidity $\left(q_{2} \mathrm{~m}\right)$; 

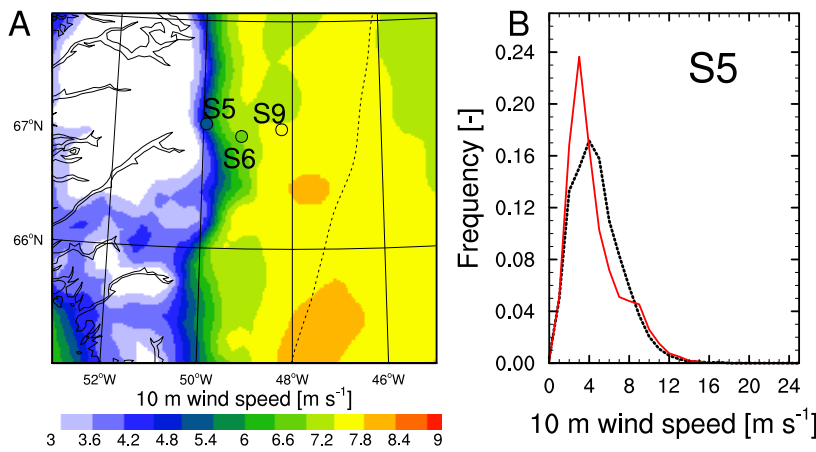
$10 \mathrm{~m}$ wind speed $\left[\mathrm{m} \mathrm{s}^{-1}\right]$
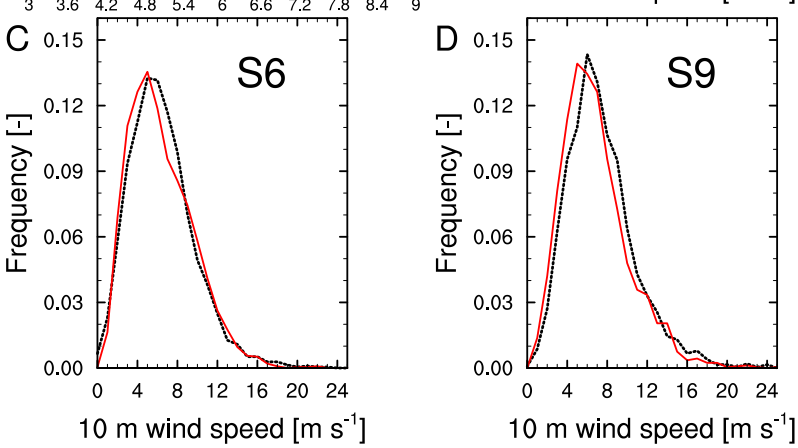

Fig. 2. (B-D) Comparison of $10 \mathrm{~m}$ wind speed frequency distributions from RACMO2 (red) and from observations (black), based on daily averages from the period 2003-2010 at 3 AWS stations along the K-transect. AWS locations are shown in panel (A), including the mean modeled (background) and observed (dots) $10 \mathrm{~m}$ wind speed.

Table 1. Comparison statistics between RACMO2 and observations presented by Ettema et al. (2010a). Shown are annual mean $2 \mathrm{~m}$ temperature $\left(T_{2} \mathrm{~m}\right), 10 \mathrm{~m}$ wind speed $\left(U_{10} \mathrm{~m}\right)$ and $2 \mathrm{~m}$ specific humidity $\left(q_{2} \mathrm{~m}\right)$.

\begin{tabular}{llrrr}
\hline & Units & $R$ & Bias & RMSE \\
\hline$T_{2} \mathrm{~m}^{\mathrm{a}}$ & $\mathrm{K}$ & 0.97 & -0.8 & 2.3 \\
$U_{10} \mathrm{~m}^{\mathrm{a}}$ & $\mathrm{m} \mathrm{s}^{-1}$ & 0.74 & 0.3 & 1.9 \\
$q_{2} \mathrm{~m}^{\mathrm{b}}$ & $\mathrm{g} \mathrm{kg}^{-1}$ & 0.98 & -0.1 & 0.3 \\
\hline
\end{tabular}

${ }^{a}$ Comparison based on 68 stations (GC-net: 15 stations, IMAU: 3 stations and DMI: 51 stations (Ettema et al., 2010a)). ${ }^{\mathrm{b}}$ Based on daily averages of the year 2004 at IMAU station $\mathrm{S} 6\left(67^{\circ} 04^{\prime} \mathrm{N}, 49^{\circ} 24^{\prime} \mathrm{W}\right)$.

these determine relative humidity, which in turn determines the potential for drifting snow sublimation (Lenaerts et al., 2010). The model evaluation is presented in the next section.

\section{Results}

\subsection{Near-surface climate}

Ettema et al. (2010a) thoroughly evaluated the near-surface climate of RACMO2, and found good agreement between model and observations. Their results are summarized in Table 1. A high correlation between modeled and observed

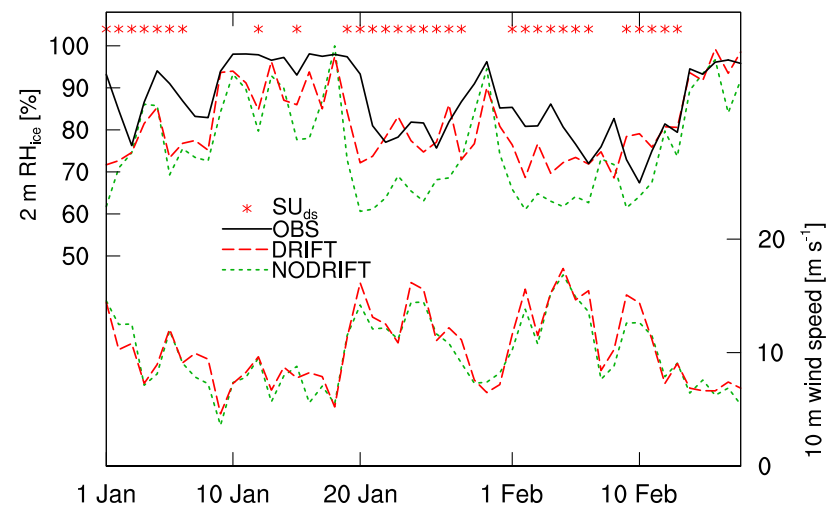

Fig. 3. Relative humidity with respect to ice at $2 \mathrm{~m}$ in January and February 2009 at the location of AWS S9. Observed $\mathrm{RH}_{\text {ice }}$ is drawn in black, the RACMO2 simulation without drifting snow (from Ettema et al., 2010a) in green and RACMO2 with drifting snow in red. The red crosses at the top indicate when $\mathrm{SU}_{\mathrm{ds}}$ occurs in RACMO2.

Table 2. Mean (1960-2011) and standard deviation (square root of the interannual variability) of ice sheet-integrated values $\left(\mathrm{Gt} \mathrm{yr}^{-1}\right)$ of the SMB and its components.

\begin{tabular}{lrr}
\hline All in Gt yr & Mean & $\sigma$ \\
\hline SMB & 376 & 118 \\
Precipitation & 723 & 74 \\
Runoff & 306 & 86 \\
$\mathrm{SU}_{\mathrm{s}}$ & 16 & 2 \\
$\mathrm{SU}_{\mathrm{ds}}$ & 24 & 3 \\
ER $_{\mathrm{ds}}$ & 1 & 1 \\
\hline
\end{tabular}

near-surface temperature $\left(T_{2} \mathrm{~m}\right)$ is found. The negative bias, which is mainly confined to the winter season, is attributed to an underestimation of downward longwave radiation (Ettema et al., 2010a). Considering that, especially for coastal stations, $10 \mathrm{~m}$ wind speed is greatly influenced by local topography that may not always be properly represented by RACMO2, the agreement between model and observations is good. High wind speeds that drive drifting snow are also well represented by RACMO2 and no clear underestimation is seen, so the model resolution appears sufficient to represent local wind climates on the ice sheet (Ettema et al., 2010a).

To further evaluate the modeled wind climate, Fig. 2 shows the frequency distributions of daily mean wind speeds from RACMO2 and AWS observations along the K-transect in southwestern Greenland (Van de Wal et al., 2005). RACMO2 realistically simulates the observed wind speed distributions at S5, S6 and S9. For drifting snow cases, especially the tail of the frequency distributions is important, which includes the very high wind speed events. The tails of the wind distributions from RACMO2 agree well with the observations at S6 and S9. RACMO2 somewhat underestimates the frequency of high wind speeds at S5, which is located on steep 


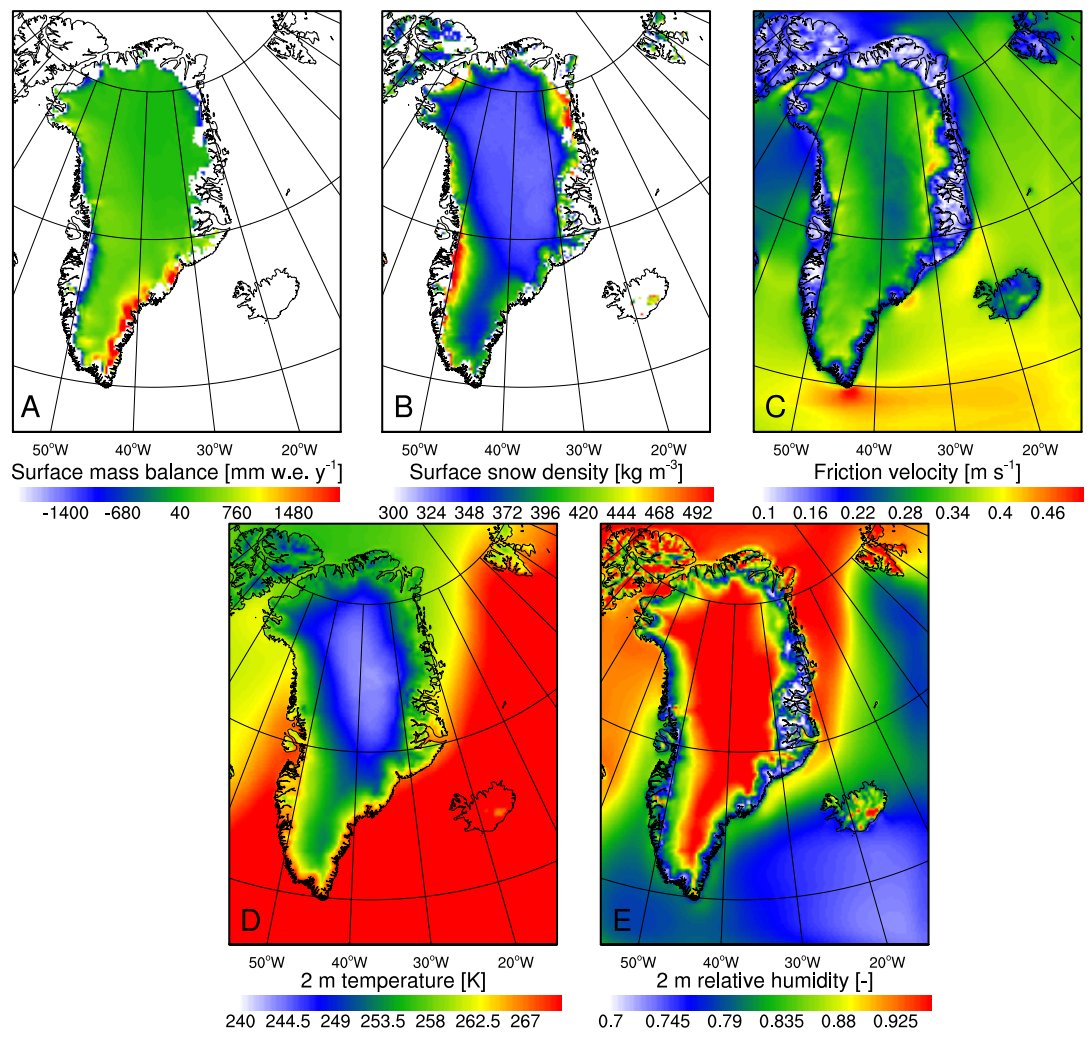

Fig. 4. Mean (1960-2011) modeled (A) surface mass balance (mm w.e. $\mathrm{yr}^{-1}$ ), (B) surface snow density $\left(\mathrm{kg} \mathrm{m}^{-3}\right)$, (C) friction velocity $\left(\mathrm{m} \mathrm{s}^{-1}\right)$, (D) $2 \mathrm{~m}$ temperature $(\mathrm{K})$ and (E) $2 \mathrm{~m}$ relative humidity w.r.t. ice (-).

slopes in rough topography that are not fully resolved by the model.

Daily mean near-surface specific humidity at S6 (Table 1) is well represented in RACMO2. At S9, however, where drifting snow occurs frequently, relative humidity is found to be underestimated in RACMO2 simulations without the drifting snow routine (Fig. 3). Including drifting snow physics strongly reduces the negative bias (Fig. 3), especially during drifting snow sublimation events. The mean bias during the period shown in Fig. 3 decreases from $13 \%$ to $7 \%$, and the RMSE reduces from $15 \%$ to $9 \%$. The reason for this improvement is that water vapor is added to the surface layer in response to $\mathrm{SU}_{\mathrm{ds}}$, increasing relative humidity in the surface layer. We conclude that it is currently hard to evaluate drifting snow in the absence of reliable direct measurements. However, indirect evidence suggests that the occurrence of drifting snow and its effect on the near-surface atmosphere are well captured.

Figure $4 \mathrm{a}-\mathrm{f}$ present the mean fields of the (near-surface) climate parameters that are important for drifting snow (sublimation). The surface mass balance (SMB, Fig. 4a) is negative ( $<-500 \mathrm{~mm}$ w.e.) along major portions of the margins, indicating that, on an annual basis, surface runoff from snowand icemelt exceeds the input of precipitation. This results in the exposure of bare glacier ice during a part of the year. On the other hand, the southeastern marginal zones are characterized by strong precipitation, and have a positive annual $\mathrm{SMB}$ of $>1 \mathrm{~m}$ w.e. The inland regions of the ice sheet are drier, but also exhibit less or no snowmelt; hence SMB $>0$. The occurrence of surface melt is also reflected in the surface snow density ( $\rho_{\mathrm{s}}$, Fig. 4b). Melt strongly increases the densification rate of the snowpack (Wakahama, 1975). This, in turn, limits the onset of drifting snow. Lenaerts et al. (2012a) show that, for a surface snow density increasing from 300 to $500 \mathrm{~kg} \mathrm{~m}^{-3}$, the associated threshold friction velocity for drifting snow $\left(u_{*, t}\right)$ increases from 0.4 to $1.2 \mathrm{~m} \mathrm{~s}^{-1}$, the latter which, for a typical surface roughness $z_{0}$ of $1 \mathrm{~mm}$, represents a $10 \mathrm{~m}$ wind speed of $>30 \mathrm{~m} \mathrm{~s}^{-1}$.

Measurements of surface snow density on the GrIS only exist for the summer season, when $\rho_{\mathrm{s}}$ is high, limiting drifting snow. An exception is the dry snow zone on the higher portions of the ice sheet, where melt does not occur, not even in summer. For these regions, we used $\rho_{\mathrm{s}}$ observations on the Antarctic ice sheet to introduce temporal and spatial variability of the surface snow density (ranging from 300 to $400 \mathrm{~kg} \mathrm{~m}^{-3}$ ), depending on the local wind and accumulation climate (Lenaerts et al., 2012a). Based on the sparse observations available, this parameterization appears to be valid on Greenland as well. For example, the observations of Bolzan and Strobel (1994) suggest a mean summer surface snow 


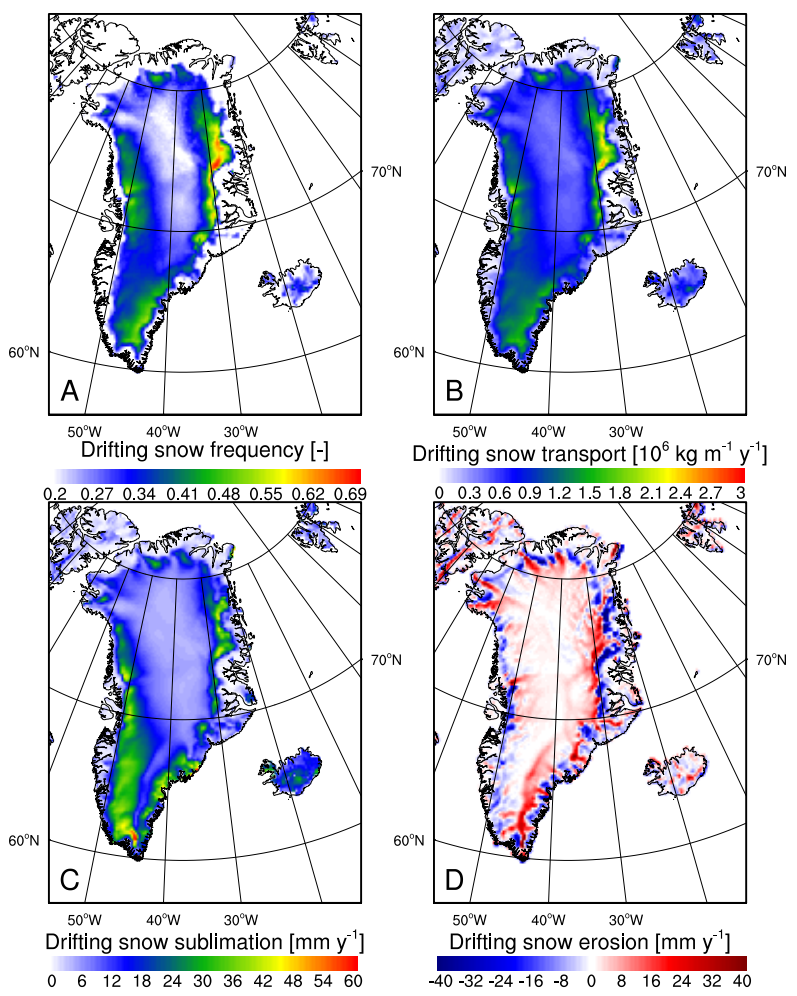

Fig. 5. Mean drifting snow frequency (A), transport (B), sublimation (C) and erosion (D). Drifting snow frequency is defined as the fraction of days with accumulated $\mathrm{TR}_{\mathrm{ds}}$ of $3 \mathrm{~kg} \mathrm{~m}^{-1}$. Dasheddotted lines represent the topography with $500 \mathrm{~m}$ intervals.

density of $332 \mathrm{~kg} \mathrm{~m}^{-3}$ (Zwally and Li, 2002). RACMO2 agrees very well with these observations, and gives a mean $\rho_{\mathrm{s}}$ in July of $330 \mathrm{~kg} \mathrm{~m}^{-3}$ in this region (Fig. 4b). Another way to assess model performance is to investigate how well the model captures the transition from winter (no melt) and summer (melt) season, as melt-induced densification limits the occurrence of drifting snow. Fettweis et al. (2011) and Van Angelen et al. (2012) show that RACMO2 is able to well simulate the onset, duration and extent of melt on the Greenland ice sheet. Although indirect evidence, this indicates that the timing and phase of the drifting snow season is well captured by the model.

Figure $4 \mathrm{c}$ shows the mean friction velocity, the parameter that combines the near-surface wind speed and surface roughness (Schmidt, 1981), (Li and Pomeroy, 1997). When the friction velocity exceeds the threshold friction velocity $\left(u_{*, t}\right)$, drifting snow is initiated. The highest average friction velocities are found in the northeastern part of the ice sheet, where katabatic forcing is largest (Van Angelen et al., 2011), along the western coast, where katabatic and synoptic forcing lead to a persistent southerly jet (Van Angelen et al., 2011), and in southern Greenland, which is under the frequent influence of midlatitude cyclones. The near-surface temperature and relative humidity are shown in Fig. $4 \mathrm{~d}$ and

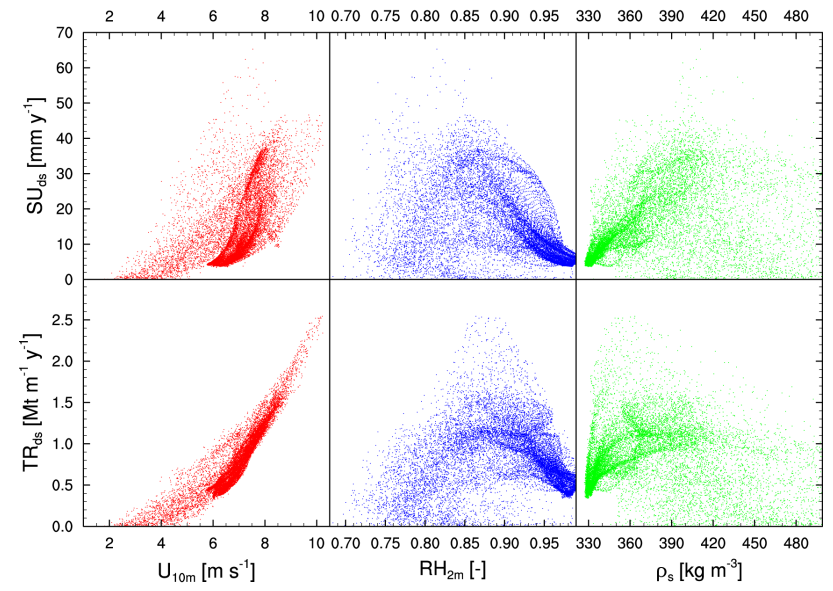

Fig. 6. Mean (1960-2011) $\mathrm{SU}_{\mathrm{ds}}$ and $\mathrm{TR}_{\mathrm{ds}}$ on all ice sheet grid points $(\sim 14000$ points) as a function of mean $10 \mathrm{~m}$ wind speed (red), $2 \mathrm{~m}$ relative humidity with respect to ice (blue) and surface snow density (green).

e, respectively. Evidently, near-surface temperature is largely determined by elevation. The highest temperatures are found along the coastline, where above-zero temperatures occur regularly in summer. Due to the low temperatures, $\mathrm{RH}_{i}$ is very high $(>95 \%)$ on higher portions of the ice sheet (> $2000 \mathrm{~m}$ ), limiting the potential for $\mathrm{SU}_{\mathrm{ds}}$, whereas the nearsurface air is less saturated at lower altitudes, where katabatic (downslope) winds give rise to adiabatic warming and subsequent drying of the near-surface air.

\subsection{Drifting snow climate}

\subsubsection{Spatial variability}

Figure 5a-d present the mean annual drifting snow frequency, transport, $\mathrm{SU}_{\mathrm{ds}}$, and $\mathrm{ER}_{\mathrm{ds}}$. Drifting snow occurs on the entire ice sheet (Fig. 5a), with frequencies ranging from $<20 \%$ in highly elevated regions, where calm conditions prevail, up to $50 \%$ and more in coastal areas. Highest drifting snow frequencies are found along the northeastern, southeastern and western margins, where the surface snow density is relatively low (Fig. 4b) and mean wind speeds are highest (Fig. 4c). Horizontal transport of drifting snow (shown as a scalar in Fig. 5a) varies from less than $0.5 \times 10^{6} \mathrm{~kg} \mathrm{~m}^{-1} \mathrm{yr}^{-1}$ on the ice sheet plateau to $>2 \times 10^{6} \mathrm{~kg} \mathrm{~m}^{-1} \mathrm{yr}^{-1}$ in the regions where drifting snow is most active. $\mathrm{SU}_{\mathrm{ds}}$ varies from $<5 \mathrm{~mm} \mathrm{yr}^{-1}$ in regions above $2500 \mathrm{~m}$ to $20-60 \mathrm{~mm} \mathrm{yr}^{-1}$ in some low-lying regions. In contrast, $\mathrm{SU}_{\mathrm{ds}}$ is small in the surrounding tundra areas, where the presence of snow on the ground is limited to the winter season, and, more importantly, near-surface wind speed is lower than on the ice sheet (Fig. 2a, Ettema et al., 2010b). $\mathrm{ER}_{\mathrm{ds}}$ is related to divergence/convergence of the near-surface (katabatic) winds and the resulting $\mathrm{TR}_{\mathrm{ds}}$. From the interior ice sheet to the margins, katabatic winds accelerate 


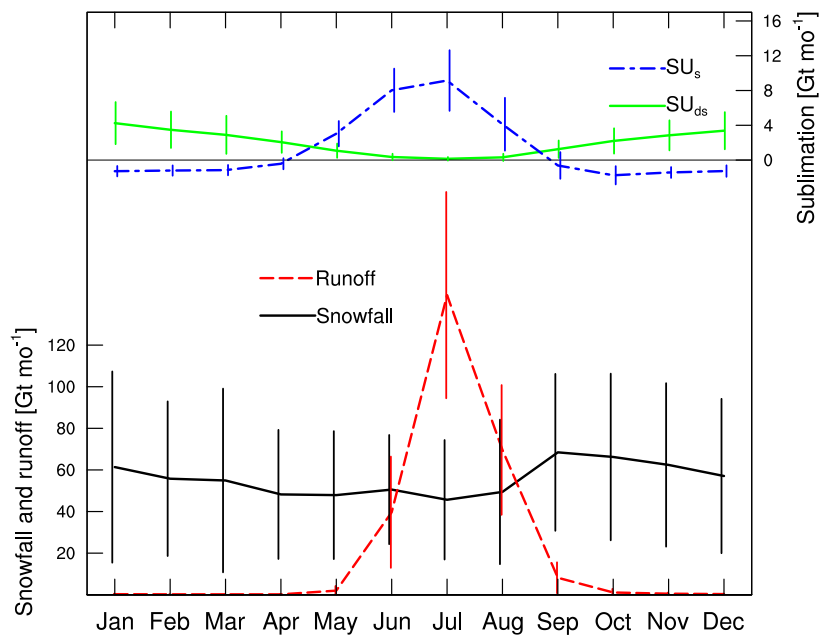

Fig. 7. Mean (1960-2011) annual cycle (January-December) of snowfall (left axis) and $\mathrm{SU}_{\mathrm{ds}}, \mathrm{SU}_{\mathrm{s}}$ and runoff (right axis), all in

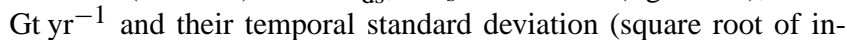
terannual variability; vertical bars denote $2 \sigma$ ). The horizontal black line represents $0 \mathrm{Gt} \mathrm{yr}^{-1}$ on the right axis.

(Van Angelen et al., 2011), leading to drifting snow erosion (10-40 $\mathrm{mm} \mathrm{yr}^{-1}$; see Fig. $5 \mathrm{~b}$ ), whereas net snow deposition occurs closer to the coast, where near-surface winds generally slow down. Patterns of alternating erosion/deposition occur where regional topography is strongly concave/convex, for example in the northwest $\left(82^{\circ} \mathrm{N}, 50-60^{\circ} \mathrm{W}\right)$. The nonlinear nature of drifting snow is evident from Fig. 6. Both $\mathrm{SU}_{\mathrm{ds}}$ and $\mathrm{TR}_{\mathrm{ds}}$ strongly depend on wind speed, but $\mathrm{SU}_{\mathrm{ds}}$ is limited when the surface layer becomes saturated. Drifting snow sublimation is therefore most active in relatively warm, windy and dry (in terms of relative humidity) regions.

Table 2 shows the ice-sheet integrated values of the SMB and its components. The 1960-2011 mean SMB of the Greenland ice sheet is estimated at $376 \pm 118 \mathrm{Gt} \mathrm{yr}^{-1}$. This estimate is comparable to other recent GrIS SMB estimates that are assembled by Rae et al. (2012), which are mostly in the range $320-450 \mathrm{Gt} \mathrm{yr}^{-1}$. Surface mass balance is largely determined by the mass input from precipitation $\left(732 \pm 74 \mathrm{Gt} \mathrm{yr}^{-1}\right)$ and the mass loss via runoff $\left(306 \pm 86 \mathrm{Gt} \mathrm{yr}^{-1}\right)$. The mass loss through sublimation is of secondary importance on Greenland. The total sublimation $\left(\mathrm{SU}_{\mathrm{ds}}+\mathrm{SU}_{\mathrm{s}}\right)$ equals $40 \pm 4 \mathrm{Gt} \mathrm{yr}^{-1}$. $\mathrm{SU}_{\mathrm{ds}}$ is responsible for $60 \%$ of the total sublimation $\left(24 \pm 3 \mathrm{Gt} \mathrm{yr}^{-1}\right)$, and $16 \pm 2 \mathrm{Gt} \mathrm{yr}^{-1}$ is lost via surface sublimation. Compared to a simulation without drifting snow (Ettema et al., 2009), total sublimation has increased by more than $40 \%$, although $\mathrm{SU}_{\mathrm{s}}$ is $40 \%$ lower; hence, including $\mathrm{SU}_{\mathrm{ds}}$ reduces $\mathrm{SU}_{\mathrm{s}}$, but increases total sublimation. Integrated over the ice sheet, $\mathrm{SU}_{\mathrm{ds}}$ is clearly smaller than runoff, and contributes $7 \%$ to the total ablation on Greenland. In comparison, $\mathrm{SU}_{\mathrm{ds}}$ is estimated to be responsible for $\sim 75 \%$ of the ablation in Antarctica (Lenaerts et al., 2012b), which highlights the large difference
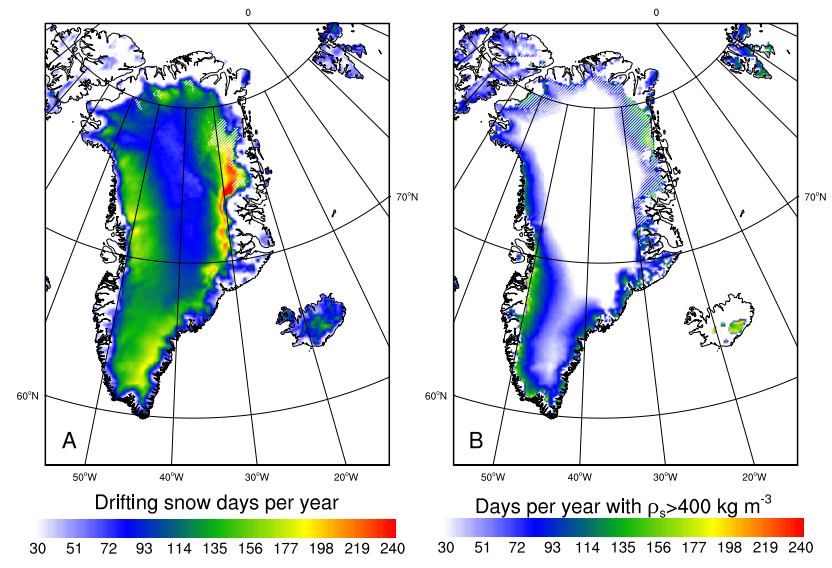

Fig. 8. Number of drifting snow days (with $\mathrm{SU}_{\mathrm{ds}}>0$ ) per year and number of days with snow density of the upper $5 \mathrm{~cm}$ of the snowpack $\left(\rho_{\mathrm{s}}\right)$ greater than $400 \mathrm{~kg} \mathrm{~m}^{-3}$. White dashes indicate areas with a standard deviation $>30$ days.

in near-surface climate between the two ice sheets. The influence of $E R_{\mathrm{ds}}$ on the Greenland surface mass balance is small $\left(1 \pm 1 \mathrm{Gt} \mathrm{yr}^{-1}\right)$. Despite their relatively small effect on ice sheet integrated $\mathrm{SMB}$, drifting snow processes $\left(\mathrm{SU}_{\mathrm{ds}}\right.$ and $\mathrm{ER}_{\mathrm{ds}}$ ) attribute largely to the local surface mass balance in relatively dry, windy regions of the Greenland ice sheet. Locally, they remove up to $50 \%$ of the precipitated snow (not shown).

\subsubsection{Seasonal variability}

All SMB components, apart from snowfall, show a clear seasonal cycle (Fig. 7). Snowfall is on average largest in early winter (September-November). Runoff and $\mathrm{SU}_{\mathrm{s}}$ peak in summer, whereas $\mathrm{SU}_{\mathrm{ds}}$ is most significant in winter. It is larger than runoff during 7 months and larger than $\mathrm{SU}_{\mathrm{s}}$ during 8 months of the year. In the winter months (DecemberFebruary), $\mathrm{SU}_{\mathrm{ds}}$ removes $\sim 6 \%$ of the snowfall.

Figure 8 shows the mean number of drifting snow days per year. Drifting snow occurs on 120-180 days in the western katabatic wind zone, and locally on $>200$ days in the north-east. The latter region not only experiences the highest katabatic wind speeds (Van Angelen et al., 2011), but also has a relatively short melt season (see Fig. 8), keeping $\rho_{\mathrm{s}}$ and $u_{*, t}$ relatively low.

An example of the transition from drifting snow season to melt season is shown in Fig. 9. It shows the annual cycle (year 2005) of drifting snow-related variables at S6, located in the ablation zone of the western ice sheet (Van den Broeke et al., 2008). In winter (January-May and October-December), the friction velocity $\left(u_{*}\right)$ often exceeds the threshold $\left(u_{*, t}\right.$, which depends on the density of the top snow layer, Gallée et al., 2001). The top snow layer is frequently refreshed by lower-density fresh snow, which keeps $u_{*, t}$ low $\left(0.3-0.4 \mathrm{~m} \mathrm{~s}^{-1}\right)$. In summer, but also during some 


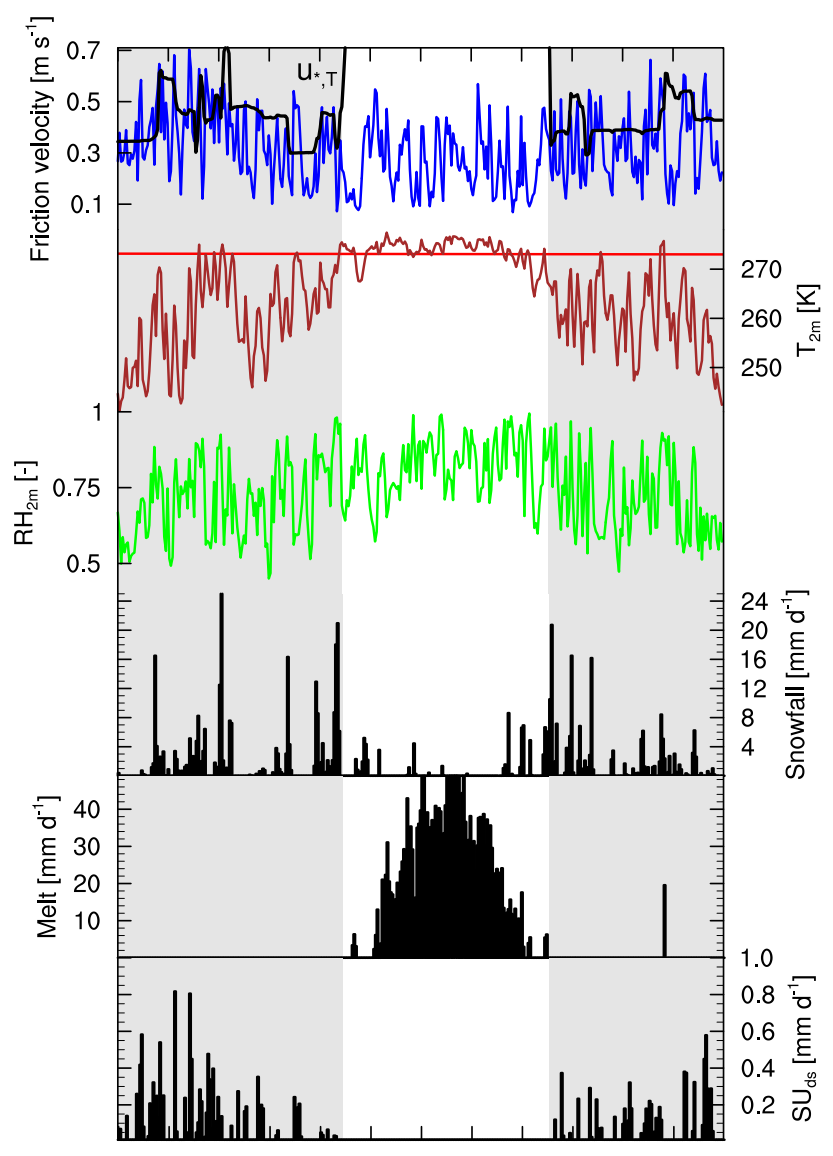

Jan Feb Mar Apr May Jun Jul Aug Sep Oct Nov Dec

Fig. 9. Modeled annual cycle $(2005)$ at $\mathrm{S} 6\left(67^{\circ} 5^{\prime} \mathrm{N}, 49^{\circ} 23^{\prime} \mathrm{W}\right)$ of daily mean friction velocity (blue) and its threshold (black, see text), $2 \mathrm{~m}$ temperature (the freezing point is illustrated by the horizontal red line) and relative humidity, daily accumulated snowfall, snowmelt and drifting snow sublimation. The grey areas represent the drifting snow season (see text).

warm episodes in winter, $u_{*, t}$ increases because of snowmelt. This strongly enhances $\rho_{\mathrm{s}}$, preventing drifting snow to occur. This illustrates the strong feedback between the length of the melt season, snow surface conditions and length of the drifting snow season in Greenland.

\subsubsection{Interannual variability and trends}

Interannual variability in $\mathrm{SU}_{\mathrm{ds}}$ is clearly related to interannual variability in near-surface wind speed (correlation coefficient $r=0.91$ ). Years with high $\mathrm{SU}_{\mathrm{ds}}$ (for example 1996) are characterized by a anomalously high near-surface wind speed and, to a lesser extent, temperature. Interestingly, the areas with the largest inter-annual variability of drifting snow frequency (Fig. 8, white dashed areas) coincide with regions where year-to-year variations in the extent of the ablation season are also largest.

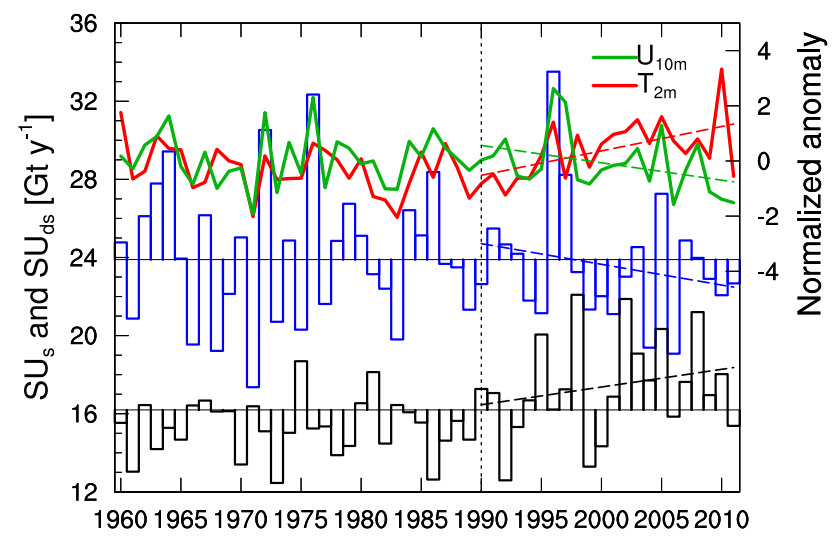

Fig. 10. Interannual variability (1960-2011) of GrIS integrated $\mathrm{SU}_{\mathrm{ds}}$ (blue bars) and $\mathrm{SU}_{\mathrm{s}}$ (black bars), combined with the normalized anomaly of GRis averaged $10 \mathrm{~m}$ wind speed $\left(U_{10} \mathrm{~m}\right.$, green) and $2 \mathrm{~m}$ temperature $\left(T_{2} \mathrm{~m}\right.$, red). The 1990-2011 linear trends are depicted by the dashed lines.

RACMO2 suggests that, in the period 1960-1990, nearsurface temperature $\left(-0.03 \pm 0.02 \mathrm{~K} \mathrm{yr}^{-1}\right)$ and wind speed $\left(0 \pm 0.003 \mathrm{~m} \mathrm{~s}^{-1} \mathrm{yr}^{-1}\right)$ trends were insignificant. Since 1990 , however, following a rise in atmospheric temperatures, meltwater runoff has been increasing (Ettema et al., 2009), only partly compensated by increased snowfall (Van den Broeke et al., 2009), which led to a strong decline in SMB. Figure 9 shows the recent trend of $\mathrm{SU}_{\mathrm{ds}}$ and $\mathrm{SU}_{\mathrm{s}}$. Since 1990, $\mathrm{SU}_{\mathrm{ds}}$ has decreased at a rate of $-0.1 \pm 0.1 \mathrm{Gt} \mathrm{yr}^{-2}$, following a $10 \mathrm{~m}$ wind speed decrease of $-0.009 \pm 0.005 \mathrm{~m} \mathrm{~s}^{-1} \mathrm{yr}^{-1}$ (Fig. 10) and the increased length of the summer season over Greenland $\left(0.6 \pm 0.9\right.$ days $\left.\mathrm{yr}^{-2}\right)$. The large uncertainty in the trend of $\mathrm{SU}_{\mathrm{ds}}$ is due to strong interannual variability, and a longer time series is required to reach significance at a $95 \%$ level. The decline in $\mathrm{SU}_{\mathrm{ds}}$ is compensated by a significant increase in $\mathrm{SU}_{\mathrm{s}}\left(+0.09 \pm 0.09 \mathrm{Gt} \mathrm{yr}^{-2}\right)$, which is related to the less frequent occurrence of drifting snow in combination with the higher near-surface temperature $\left(+0.09 \pm 0.03 \mathrm{~K} \mathrm{yr}^{-1}\right)$.

\section{Conclusions}

This paper describes the first attempt to simulate the drifting snow climate of the Greenland ice sheet, using output of a high-resolution $(11 \mathrm{~km})$ regional climate model (RACMO2) with interactive drifting snow routine for a period of $52 \mathrm{yr}$ (1960-2011). RACMO2 is able to realistically model the near-surface climate of Greenland (Ettema et al., 2010a), and it includes a snow albedo scheme that tracks the evolution of snow grain size and a drifting snow routine that allows for interaction between drifting snow, the snow surface and the overlying atmosphere (Lenaerts and van den Broeke, 2012). 
We evaluated the results in terms of the near-surface climate in further detail, because a direct evaluation of the drifting snow climate is not feasible. RACMO2 shows realistic wind speed spectra along the K-transect. Furthermore, we showed that, during drifting snow, $\mathrm{SU}_{\mathrm{ds}}$ enhances near-surface relative humidity, which improves the agreement with observations. Unfortunately, because no reliable direct observations of drifting snow transport or frequency are available for Greenland, we are presently unable to explicitly/directly evaluate and/or further improve the drifting snow model.

The results show that drifting snow in Greenland is not significant during summer, when near-surface wind speeds are lower and surface snow density and associated threshold friction velocity increase due to melt, which suppresses drifting snow to occur. In winter, during 7 months of the year, $\mathrm{SU}_{\mathrm{ds}}$ is the only important ablation mechanism, removing $\sim 6 \%$ of the precipitation during this period. In summer, $\mathrm{SU}_{\mathrm{ds}}$ is negligible, and meltwater runoff becomes the primary ablation component. Integrated over the Greenland ice sheet, $\mathrm{SU}_{\mathrm{ds}}$ equals $24 \mathrm{Gt} \mathrm{yr}^{-1}, 50 \%$ larger than $\mathrm{SU}_{\mathrm{s}}$ $\left(16 \mathrm{Gt} \mathrm{yr}^{-1}\right)$. Although the contribution of drifting snow erosion $\left(E_{\mathrm{ds}}\right)$ to the surface mass balance is negligible on the ice sheet, it is locally of importance, especially in areas where topographic features induce strong wind field divergence/convergence. An abrupt transition occurs between the melting season in summer, when drifting snow is strongly suppressed, and the drifting snow season, when light, fresh snow is prone to drifting.

Acknowledgements. We thank the editor, R. Dadic and an anonymous reviewer for their helpful comments. This work was supported by funding from the ice2sea programme from the $\mathrm{Eu}-$ ropean Union 7th Framework Programme, grant number 226375. Ice 2 sea contribution number 092.

Edited by: V. Radic

\section{References}

Bintanja, R.: Modelling snowdrift sublimation and its effect on the moisture budget of the atmospheric boundary layer, Tellus A, 53, 215-232, 2001.

Bolzan, J. F. and Strobel, M.: Accumulation-rate variations around Summit, Greenland, J. Glaciol., 40, 56-66, 1994.

Box, J. E. and Cohen, A. E.: Upper-air temperatures around Greenland: 1964-2005, Geophys. Res. Lett., 33, L12706, doi:10.1029/2006GL025723, 2006.

Box, J. E., Bromwich, D. H., Veenhuis, B. A., Bai, L. S., Stroeve, J. C., Rogers, J. C., Steffen, K., Haran, T., and Wang, S. H.: Greenland ice sheet surface mass balance variability (1988-2004) from calibrated polar MM5 output, J. Climate, 19, 2783-2800, 2006.

Cierco, F.-X., Naaim-Bouvet, F., and Bellot, H.: Acoustic sensors for snowdrift measurements: how should they be used for research purposes?, Cold Reg. Sci. Technol., 49, 74-87, doi:10.1016/j.coldregions.2007.01.002, 2007.

Déry, S. J. and Yau, M. K.: A bulk blowing snow model, Bound.Lay. Meteorol., 93, 237-251, 1999.

Déry, S. J. and Yau, M. K.: Large-scale mass balance effects of blowing snow and surface sublimation, J. Geophys. Res., 107, 4679, doi:10.1029/2001JD001251, 2002.

Ettema, J., van den Broeke, M. R., van Meijgaard, E., van de Berg, W. J., Bamber, J. L., Box, J. E., and Bales, R. C.: Higher surface mass balance of the Greenland ice sheet revealed by highresolution climate modeling, Geophys. Res. Lett., 36, L12501, doi:10.1029/2009GL038110, 2009.

Ettema, J., van den Broeke, M. R., van Meijgaard, E., van de Berg, W. J., Box, J. E., and Steffen, K.: Climate of the Greenland ice sheet using a high-resolution climate model - Part 1: Evaluation, The Cryosphere, 4, 511-527, doi:10.5194/tc-4511-2010, 2010a.

Ettema, J., van den Broeke, M. R., van Meijgaard, E., and van de Berg, W. J.: Climate of the Greenland ice sheet using a high-resolution climate model - Part 2: Near-surface climate and energy balance, The Cryosphere, 4, 529-544, doi:10.5194/tc-4529-2010, 2010 b.

Fettweis, X.: Reconstruction of the 1979-2006 Greenland ice sheet surface mass balance using the regional climate model MAR, The Cryosphere, 1, 21-40, doi:10.5194/tc-1-21-2007, 2007.

Fettweis, X., Tedesco, M., van den Broeke, M., and Ettema, J.: Melting trends over the Greenland ice sheet (1958-2009) from spaceborne microwave data and regional climate models, The Cryosphere, 5, 359-375, doi:10.5194/tc-5-359-2011, 2011.

Flanner, M. and Zender, C.: Linking snowpack microphysics and albedo evolution, J. Geophys. Res., 111, D12208, doi:10.1029/2005JD006834, 2006.

Gallée, H., Guyomarch, G., and Brun, E.: Impact of snow drift on the Antarctic Ice Sheet surface mass balance: possible sensitivity to snow-surface properties, Bound.-Lay. Meteorol., 99, 1-19, 2001.

Hanna, E., Huybrechts, P., Janssens, I., Cappelen, J., Steffen, K., and Stephens, A.: Runoff and mass balance of the Greenland Ice Sheet: 1958-2003, J. Geophys. Res., 110, D13108, doi:10.1029/2004JD005641, 2005.

Holland, D. M., Thomas, R. H., de Young, B., Ribergaard, M. H., and Lyberth, B.: Acceleration of Jacobshavn Isbrae triggered by warm subsurface ocean waters, Nat. Geosci., 1, 659-664, doi:10.1038/ngeo316, 2008.

Kuipers Munneke, P., van den Broeke, M. R., Lenaerts, J. T. M., Flanner, M. G., Gardner, A., and van de Berg, W. J.: A new albedo scheme for use in climate models over the Antarctic ice sheet, J. Geophys. Res., 116, D05114, doi:10.1029/2010JD015113, 2011.

Lenaerts, J. T. M. and van den Broeke, M. R.: Regional climate modeling of drifting snow in Antarctica, Part 2: Results, J. Geophys. Res., 117, D05109, doi:10.1029/2010JD015419, 2012.

Lenaerts, J. T. M., van den Broeke, M. R., Déry, S. J., KönigLanglo, G., Ettema, J., and Munneke, P. K.: Modelling snowdrift sublimation on an Antarctic ice shelf, The Cryosphere, 4, 179190, doi:10.5194/tc-4-179-2010, 2010.

Lenaerts, J. T. M., van den Broeke, M. R., Déry, S. J., van Meijgaard, E., van de Berg, W. J., Palm, S. P., and Sanz Rodrigo, J.: Regional climate modeling of drifting snow in Antarctica, Part I: 
Methods and model evaluation, J. Geophys. Res., 117, D05108, doi:10.1029/2011JD016145, 2012a.

Lenaerts, J. T. M., van den Broeke, M. R., van de Berg, W. J., van Meijgaard, E., and Kuipers Munneke, P.: A new, high-resolution surface mass balance map of Antarctica (1979-2010) based on regional atmospheric climate modeling, Geophys. Res. Lett., 39, L04501, doi:10.1029/2011GL050713, 2012b.

Li, L. and Pomeroy, J. W.: Estimates of threshold wind speeds for snow transport using meteorological data, J. Appl. Meteorol., 36, 205-213, 1997.

Nick, F. M., Vieli, A., Howat, I. M., and Joughin, I.: Large-scale changes in Greenland outlet glacier dynamics triggered at the terminus, Nat. Geosci., 2, 110-114, doi:10.1038/ngeo394, 2009.

Palm, S. P., Yang, Y., Spinhirne, J., and Marshak, A.: Satellite remote sensing of blowing snow properties over Antarctica, J. Geophys. Res., 116, D16123, doi:10.1029/2011JD015828, 2011.

Rae, J. G. L., Aðalgeirsdóttir, G., Edwards, T. L., Fettweis, X., Gregory, J. M., Hewitt, H. T., Lowe, J. A., Lucas-Picher, P., Mottram, R. H., Payne, A. J., Ridley, J. K., Shannon, S. R., van de Berg, W. J., van de Wal, R. S. W., and van den Broeke, M. R.: Greenland ice sheet surface mass balance: evaluating simulations and making projections with regional climate models, The Cryosphere Discuss., 6, 2059-2113, doi:10.5194/tcd-6-2059-2012, 2012.

Rignot, E., Velicogna, I., van den Broeke, M. R., Monaghan, A., and Lenaerts, J. T. M.: Acceleration of the contribution of Greenland and Antarctic ice sheets to sea level rise, Geophys. Res. Lett., 38, L05503, doi:10.1029/2011GL046583, 2011.

Schmidt, R.: Estimates of threshold windspeed from particle sizes in blowing snow, Cold Reg. Sci. Technol., 4, 187-193, doi:10.1016/0165-232X(81)90003-3, 1981.

Straneo, F., Curry, R. G., Sutherland, D. A., Hamilton, G. S., Cenedese, C., Våge, K., and Stearns, L. A.: Impact of of fjords dynamics and glacial runoff on the circulation near Helheim glacier, Nat. Geosci., 4, 322-327, doi:10.1038/ngeo1109, 2011.

Tedesco, M., Fettweis, X., van den Broeke, M. R., van de Wal, R. S. W., Smeets, C. J. P. P., van de Berg, W. J., Serreze, M. C., and Box, J. E.: The role of albedo and accumulation in the 2010 melting record in Greenland, Environ. Res. Lett., 6, 014005, doi:10.1088/1748-9326/6/1/014005, 2010.

Undén, P., Rontu, L., Järvinen, H., Lynch, P., Calvo, J., Cats, G., Cuxart, J., Eerola, K., Fortelius, C., Garcia-Moya, J., Jones, C., Lenderlink, G., McDonald, A., McGrath, R., Navascues, B., Nielsen, N. W., Ødegaard, V., Rodriguez, E., Rummukainen, M., Rǒǒm, R., Sattler, K., Sass, B. H., Savijärvi, H., Schreur, B. W., Sigg, R., The, H., and Tijm, A.: HIRLAM-5 Scientific Documentation, Tech. rep., Swed. Meteorol. and Hydrol. Inst., Norrköping, Sweden, 2002. van Angelen, J. H., van den Broeke, M. R., and van de Berg, W. J.: Momentum budget of the atmospheric boundary layer over the Greenland ice sheet and its surrounding seas, J. Geophys. Res., 115, D10101, doi:10.1029/2010JD015485, 2011.

van Angelen, J. H., Lenaerts, J. T. M., Lhermitte, S., Fettweis, X., Kuipers Munneke, P., van den Broeke, M. R., and van Meijgaard, E.: Sensitivity of Greenland Ice Sheet surface mass balance to surface albedo parameterization: a study with a regional climate model, The Cryosphere Discuss., 6, 1531-1562, doi:10.5194/tcd-6-1531-2012, 2012.

van de Berg, W. J., van den Broeke, M. R., Reijmer, C. H., and van Meijgaard, E.: Characteristics of the Antarctic surface mass balance (1958-2002) using a regional atmospheric climate model, Ann. Glaciol., 41, 97-104, 2005.

van de Wal, R., Greuell, W., van den Broeke, M., Reijmer, C., and Oerlemans, J.: Surface mass-balance observations and automatic weather station data along a transect near Kangerlussuaq, West Greenland, Ann. Glaciol., 42, 311-316, 2005.

van den Broeke, M. R., Smeets, C. J. P. P., Ettema, J., and Kuipers Munneke, P.: Surface radiation balance in the ablation zone of the west Greenland ice sheet, J. Geophys. Res., 113, D13105, doi:10.1029/2007JD009283, 2008.

van den Broeke, M. R., Bamber, J. L., Ettema, J., Rignot, E., Schrama, E., van de Berg, W. J., van Meijgaard, E., Velicogna, I., and Wouters, B.: Partitioning recent Greenland mass loss, Science, 326, 984-986, doi:10.1126/science.1178176, 2009.

van Meijgaard, E., van Ulft, L. H., van de Berg, W. J., Bosvelt, F. C., van den Hurk, B. J. J. M., Lenderink, G., and Siebesma, A. P.: The KNMI regional atmospheric model RACMO version 2.1, Tech. Rep. 302, KNMI, De Bilt, The Netherlands, 2008.

Wakahama, G.: The Role of Meltwater in Densification Processes of Snow and Firn, in: Snow Mechanics Symposium; Proceedings of the Grindelwald Symposium, Grindelwald, Bernese Oberland (Switzerland), April 1974, 114, International Association of Hydrological Sciences, 1975.

White, P.: Physical processes (CY23R4), Tech. rep., European Centre for Medium-Range Weather Forecasts (ECMWF), 2001.

Zwally, H. and Li, J.: Seasonal and interannual variations of firn densification and ice-sheet surface elevation at the greenland summit, J. Glaciol., 48, 199-207, 2002. 